\title{
Clinicopathological Study of Congenital Anomalies in Urogenital Tract in Infants and Children
}

\author{
Dinesh Pratap Singh ${ }^{1}$, Kamta Prasad Gupta ${ }^{1}$, Moh. Hanif Bhat ${ }^{2}$, Shahnawaz Hussain Siddiqui ${ }^{3}$ \\ ${ }^{1}$ Assistant Professor, Department of Surgery, Varun Arjun Medical College and Rohilkhand Hospital, Banthara, Shahjahanpur, ${ }^{2}$ Senior Resident, \\ Department of Surgery, Varun Arjun Medical College and Rohilkhand Hospital Banthara Shahjahanpur, ${ }^{3}$ Senior Resident, Department of Surgery, Varun \\ Arjun Medical College and Rohilkhand Hospital, Banthara, Shahjahanpur.
}

\section{Abstract}

Background: Congenital abnormalities and malformations are more frequent in the urinary tract than in any other system of the body. The present study was conducted to evaluate incidence of congenital anomalies in urogenital tract in infants and children. Subjects and Methods: The present study was conducted on 55 cases age ranged 6 months to 8 years of congenital anomalies of urogenital tract which were admitted in department of Pediatric surgery ward of Kamla Nehru hospital, Bhopal during 1 year period. Type of anamoly was also recorded. In all patients, thorough clinical examination was performed. USG was done in all cases to confirm the cases. Results: Out of 1500 pediatric admissions, $56(3.6 \%)$ had anomalies in urinary tract. In males, maximum lesions were hyposposdias seen in 13 followed by VUR \& PUV in 12 patients and phimosis in 6 and 1 case of diphallia was found. In females, maximum lesions were congenital hydronephnosis, pelvic kidney, horse shoe kidney, ectopic ureter and ectopia vesicae seen in 1 patient each. Increased frequency of micturition was seen in 16, urine through ureter opening was seen in 12, dribbling of urine in 15 and suprapubic swelling was observed in 8 cases. USG revealed congenital hydronephnosis in 2, PUJ obstruction in 2, pelvic kidney in 2, ectopia vesicae in 2, ureterocele in 2. Conclusion: Authors found that maximum cases were of Hyposposdias followed by VUR \& PUV and phimosis.

Keywords: Congenital abnormalities, Hyposposdias, Urinary tract.

Corresponding Author: Dr. Kamta Prasad Gupta, Assistant Professor, Department of Surgery, Varun Arjun Medical College and Rohilkhand Hospital, Banthara, Shahjahanpur.

Received: March 2019

Accepted: April 2019

\section{Introduction}

Congenital abnormalities and malformations are more frequent in the urinary tract than in any other system of the body, and it is an interesting and important fact that they are very commonly multiple. It is quite usual to find both kidneys and ureters involved, or to find bladder and penile deformities with faulty development of one or both kidneys and ureters. Many of them cause little or no disability and are discovered incidentally during a urological or post-mortem examination. ${ }^{[1]}$

On the other hand, some few are incompatible with life, and by far the greater number gives rise to serious disabilities, chronic illnesses and often a shortened life. Various anomalies of urinary tract are commonly seen in patients such as posterior urethral valves, primary bladder neck contracture, cysts of utricle, hypospadias, epispadias, cryptoorchidism etc. ${ }^{[2]}$

Fusion of the kidneys has been recorded in a great variety of forms, the commonest being the horseshoe type. The two kidneys are joined together by their lower poles across the front of the aorta and vena cava; rarely cases have been recorded where the junction was between the upper poles. ${ }^{[3]}$ The union is of varying thickness and may be of fibrous tissue only, but usually consists of renal parenchyma, and may be large enough to be felt lying across the front of the vertebra.4 The present study was conducted to evaluate incidence of congenital anomalies in urogenital tract in infants and children and to study correlation between congenital anomalies of urogenital tract and urinary tract infection in infants and children.

\section{Subjects and Methods}

The present study was conducted in the department of general surgery. It comprised of 56 cases age ranged 6 months to 8 years of congenital anomalies of urogenital tract which were admitted in department of Pediatric surgery ward of Kamla Nehru hospital, Bhopal during 1 year period. The study protocol was approved from institutional ethical committee. The informed written consent was taken from parents.

General information such as name, age, gender etc. was recorded. Type of anamoly was also recorded. In all patients, thorough clinical examination was performed. USG was done in all cases to confirm the cases. Surgical management 
was done. Results thus obtained were subjected to statistical analysis. $\mathrm{P}$ value less than 0.05 was considered significant.

\section{Results}

Table 1: Incidence of congenital anomalies of urogenital tract

\begin{tabular}{|l|l|l|}
\hline $\begin{array}{l}\text { Total pediatric } \\
\text { admission }\end{array}$ & $\begin{array}{l}\text { Total anomalies in } \\
\text { urinary tract }\end{array}$ & Percentage \\
\hline 1500 & 56 & $3.6 \%$ \\
\hline
\end{tabular}

[Table 1] shows that out of 1500 pediatric admissions, 56 $(3.6 \%)$ had anomalies in urinary tract.

\section{Table 2: Type of congenital anomalies}

\begin{tabular}{|l|l|l|}
\hline Abnormality & Male & Female \\
\hline Hyposposdias & 13 & 0 \\
\hline Epispadias & 2 & 0 \\
\hline Congenital hydronephnosis & 1 & 1 \\
\hline PUJ obstruction & 2 & 0 \\
\hline Pelvic kidney & 0 & 1 \\
\hline Diphallia & 1 & 0 \\
\hline Meatus Stenosis & 2 & 0 \\
\hline Urethral Structure & 2 & 0 \\
\hline Horse shoe kidney & 0 & 1 \\
\hline Ectopic ureter & 0 & 1 \\
\hline Ectopia vesicae & 1 & 1 \\
\hline Bladder diverticula & 1 & 0 \\
\hline Ureterocele & 2 & 0 \\
\hline VUR \& PUV & 12 & 0 \\
\hline Agenesis of kidney & 1 & 0 \\
\hline Phimosis & 6 & 0 \\
\hline Underdescended testes & 5 & 0 \\
\hline Total & 56 & 5 \\
\hline
\end{tabular}

[Table 2] shows that in males, maximum lesions were hyposposdias seen in 13 followed by VUR \& PUV in 12 patients and phimosis in 6 and one case of diphallia [Photograph 1]. In females, maximum lesions were congenital hydronephnosis, pelvic kidney, horse shoe kidney, ectopic ureter and ectopia vesicae seen in 1 patient each.

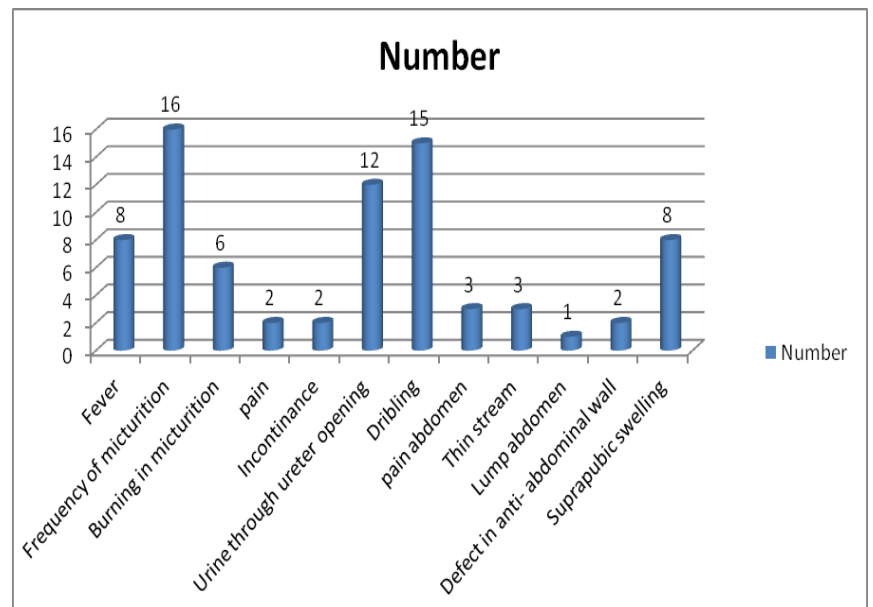

Figure 1: Relationship of urinary symptology with their frequency of occurrence in congenital anomalies of urinary tract

[Figure 1] shows that increased frequency of micturition was seen in 16, urine through ureter opening was seen in 12 , dribbling of urine in 15 and suprapubic swelling was observed in 8 cases.

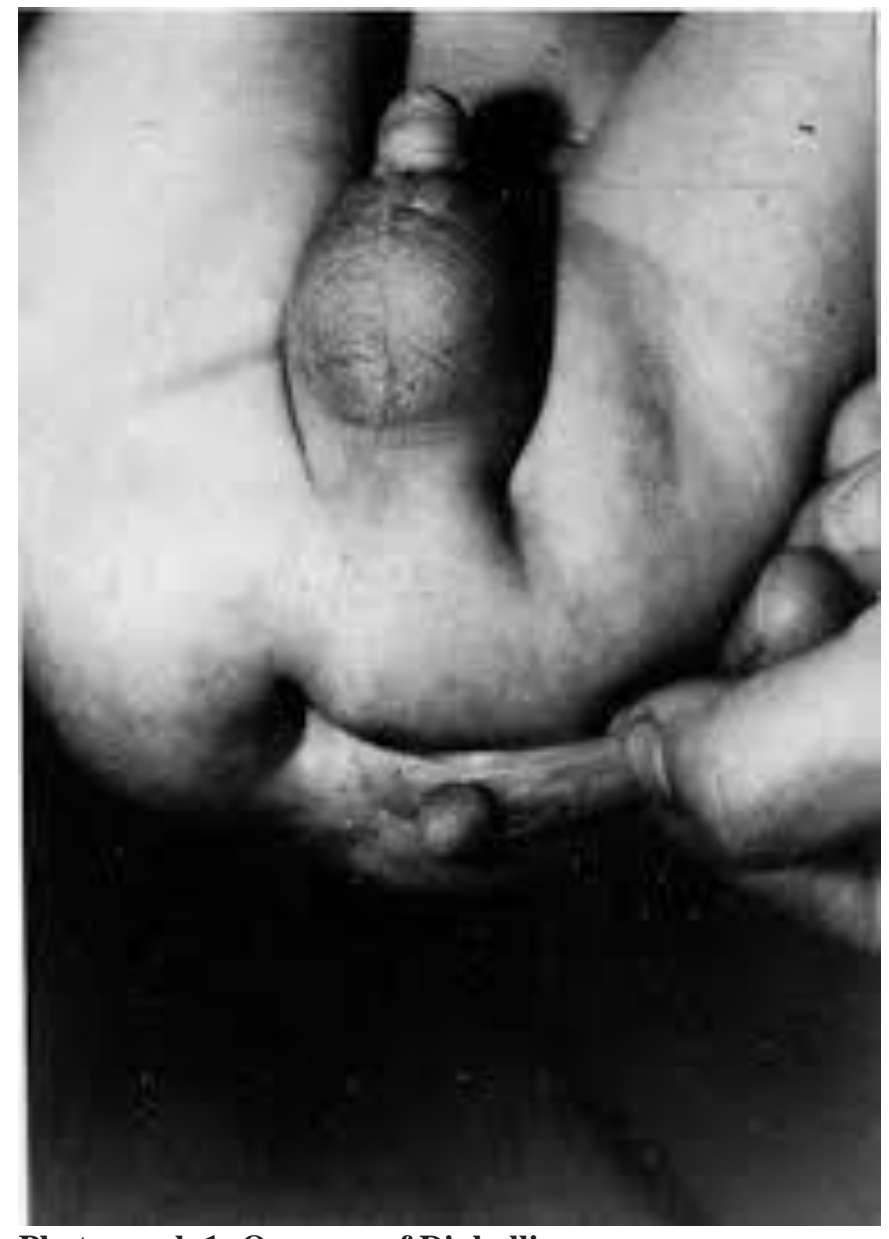

Photograph 1: One case of Diphallia

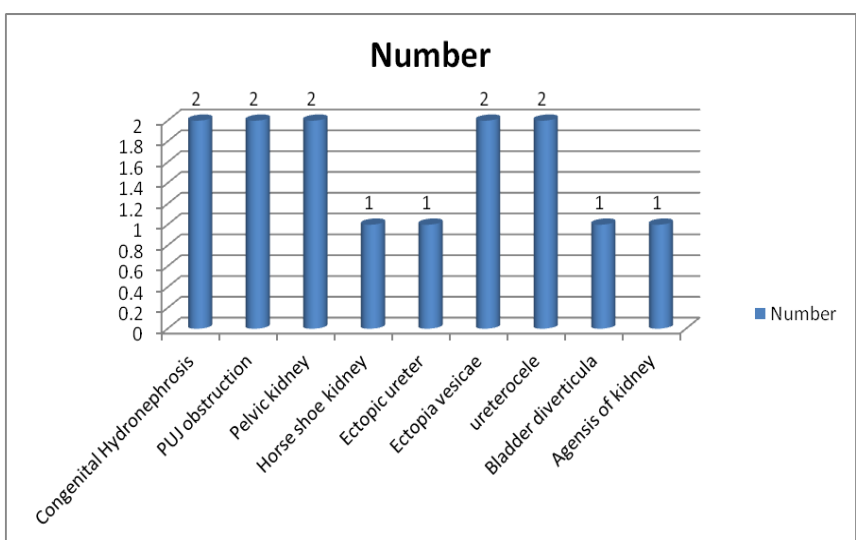

Figure 2: Abnormal finding of various type of congenital anamoly in urinary tract USG of abdomen

[Figure 2] shows that USG revealed congenital hydronephnosis in 2, PUJ obstruction in 2, pelvic kidney in 2 , ectopia vesicae in 2 , ureterocele in 2 .

\section{Discussion}

Polycystic kidney disease, a disorder that can be diagnosed in adult and pediatric patients, is an inherited disease that involves bilateral renal cysts without dysplasia. The condition is broadly divided into 2 forms: autosomal recessive polycystic kidney disease, previously known as 
infantile polycystic kidney disease, and autosomal dominant polycystic kidney disease, previously known as adult polycystic kidney disease. ${ }^{[5]}$

Renal agenesis is absence of one or both kidneys. Sometimes imaging tests will show a very small kidney in an abnormal position. Renal hypoplasia is when part or the whole kidney does not fully develop in the womb. It is smaller than normal. Small size means that the kidney does not function as well as a normal kidney. ${ }^{[6]}$ One or both kidneys may be affected. It does not seem to be passed down from parents to children. It occurs equally in boys and girls. Kidney size is linked to the chance of problems in the future. If a child's kidneys are very small, kidney function may decrease as the child enters teenage years. Kidney failure may occur, which would call for supportive measures. ${ }^{[7]}$ The present study was conducted to evaluate incidence of congenital anomalies in urogenital tract in infants and children and to study correlation between congenital anomalies of urogenital tract and urinary tract infection in infants and children.

In present study, out of 1500 pediatric admissions, 56 (3.6\%) had anomalies in urinary tract. In males, maximum lesions were hyposposdias seen in 13 followed by VUR \& PUV in 12 patients, phimosis in 6 and 1 case of diphallia. In females, maximum lesions were congenital hydronephnosis, pelvic kidney, horse shoe kidney, ectopic ureter and ectopia vesicae seen in 1 patient each.

Nakanishi et al, ${ }^{[8]}$ in their study assessed congenital renal and urinary tract anomalies by postnatal ultrasound and to study the pattern of distribution, clinical presentation and its correlation with antenatal scan. Postnatal ultrasound of 40 subjects fulfilling the inclusion criteria was performed on 4th day of life. Postnatal ultrasound findings were compared with antenatal records and immediate postnatal clinical course was assessed. Out of 40 high-risk selected screen patients, 14 subjects were identified to have CAKUT on postnatal USG on 4th day of life. Hydronephrosis was the most common congenital renal anomaly with statistically good correlation with antenatal and postnatal scan (P
$<0.0001)$. Mild hydronephrosis detected on antenatal scan (with anterior pelvic diameter 7-9 $\mathrm{mm}$ ) showed resolution on postnatal ultrasound in 3 subjects. The congenital anomalies in 4 cases were missed on antenatal USG. The number of LBW babies in the screened population was $60 \%$ and $64 \%$ babies with CAKUT were LBW. Family predisposition was seen in $12.5 \%$ of CAKUT population.

We observed that increased frequency of micturition was seen in 16, urine through ureter opening was seen in 12 , dribbling of urine in 15 and suprapubic swelling was observed in 8 cases. USG revealed congenital hydronephnosis in 2, PUJ obstruction in 2, pelvic kidney in 2 , ectopia vesicae in 2 , ureterocele in 2 .

\section{Conclusion}

Authors found that maximum cases were of Hyposposdias followed by VUR \& PUV and phimosis.

\section{References}

1. Ihor V Yosypiv. Congenital anomalies of the kidney and urinary tract: a genetic disorder? International Journal of Nephrology. 2012;1-10.

2. Elder JS. Antenatal hydronephrosis: fetal and neonatal management. Pediatr Clin N Am 1997;44(5):1299-1321.

3. Fasolato V, Poloniato A, Bianchi C, et al. Fetoneonatal ultrasonography to detect renal abnormalities: evaluation of 1-year screening program. Am J Perinatol 1998;15(3):161-4.

4. Riccipetitoni G, Chierici R, Tamisari L, et al. Postnatal ultrasound screening of urinary malformations. J Urol 1992;148(2 Pt 2):604-5.

5. Arvind Bagga. Consensus statement on management of antenatally detected hydronephrosis. Indian Pediatrics 2001;38:1244-1251.

6. Nguyen HT, Herndon CD, Cooper C, et al. The society for fetal urology consensus statement on the evaluation and management of antenatal hydronephrosis. Journal of Pediatric Urology 2010;6(3):212-31.

7. Daneman, Alton DJ. Radiographic manifestations of renal anomalies. Radiologic Clinics of North America 1991;29(2):351-363.

8. Nakanishi K, Yoshikawa N. Genetic disorders of human congenital anomalies of the kidney and urinary tract (CAKUT). Pediatrics International 2003;45(5):610-616.

Copyright: () the author(s), 2019. It is an open-access article distributed under the terms of the Creative Commons Attribution License (CC BY 4.0), which permits authors to retain ownership of the copyright for their content, and allow anyone to download, reuse, reprint, modify, distribute and/or copy the content as long as the original authors and source are cited.

How to cite this article: Singh DP, Gupta KP, Bhat MH, Siddiqui SH. Clinicopathological Study of Congenital Anomalies in Urogenital Tract in Infants and Children. Acad. J Surg. 2019;2(1):1-3.

DOI: dx.doi.org/10.21276/ajs.2019.2.1.1

Source of Support: Nil, Conflict of Interest: None declared. 